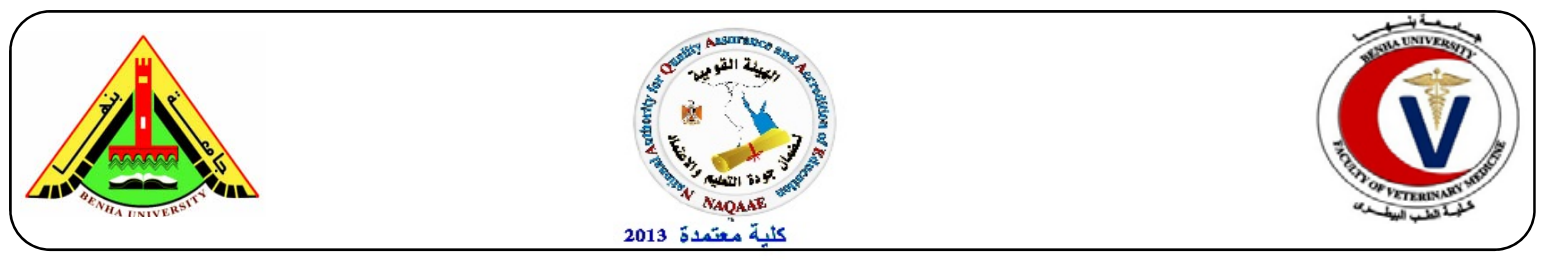

\title{
Incidence of Vibrio species in fish with special emphasis on the effect of heat treatments
}

\author{
Saad Mahmoud Saad ${ }^{1}$, Maha Mohammed Samir'², Hania El Sayed Abd El Maksod \\ ${ }^{1}$ Food Control Department, Faculty of Veterinary Medicine, Benha University, ${ }^{2}$ Food Control \\ Department, Animal Health Research Institute, Zagazig Branch
}

\section{A B S T R A C T}

A grand total of 150 random samples of fresh water fish (Tilapia nilotica), marine water fish (Mugil cephalus), and farm water fish (Tilapia nilotica) fish (50 of each) were collected from Sharkia governor during summer of 2014 to investigate the incidence of Vibrio spp. as well as studying the effect of heat treatments (frying and roasting). The obtained results revealed that incidence of Vibrio spp. in fresh water fish were $13(26 \%)$, the overall incidence in the samples was $4(8 \%)$ for $V$. vulnificus, and $2(4 \%)$, $2(4 \%), 2(4 \%), 2(4 \%)$ and $1(2 \%)$ for, $V$. mimicus, $V$. fluvialis, $V$. damsel, $V$. furnissi, and $V$. alginolyticus, respectively. In marine fish Vibrio spp. were $24(48 \%)$, the overall incidence in the samples was for $V$. parahaemolyticus $5(10 \%)$, V. vulnificus $4(8 \%)$, V. fluvialis4 (8\%), V. mimicus $7(14 \%)$, V. alginolyticus 2(4\%), and $V$. damsel 2(4\%). In farm water fish Vibrio spp. were 17(34\%) while the overall incidence in the samples was $V$. parahaemolyticus $1(2 \%)$, V. vulnificus $3(6 \%)$, V. fluvialis $3(6 \%), V$. mimicus $5(10 \%), V$. alginolyticus $2(4 \%)$, and $V$. damsela $3(6 \%)$. Ten pieces of fish fillet (100g of each and 5 pieces for each treatment) were used to study the effect of frying with cotton seed oil (1900 C) for 10 minutes and roasting in oven at $1500 \mathrm{C}$ for 10 minutes after their inoculation with $106 \mathrm{cfu} / \mathrm{g} \mathrm{V}$. paraheamolyticus. After roasting and frying, the microbial counts of V. paraheamolyticus were decreased by $98.2 \%$ and $100 \%$, respectively.

Keywords: Vibrio spp., fresh water fish, marine fish, farm water fish, V. paraheamolyticus, heat treatment.

\section{INTRODUCTION}

$\mathrm{F}$ ish is a nutrient-rich part of a healthful diet, and its consumption is associated with potential health benefits (Hibbeln et al., 2007) Fish and their products are responsible for a substantial proportion of foodborne diseases worldwide pathogen such as Campylobacter, Salmonella, Vibrios, Listeria monocytogenes and Escherichia coli $\mathrm{O} 157: \mathrm{H} 7$ have been found to be responsible for major food borne outbreaks worldwide (Velusamy et al., 2010). Vibrios are Gram-negative, rod-shaped bacteria that occur naturally in estuarine or marine environments. Infection is usually occur from exposure to seawater or consumption of raw or undercooked fish (Altekruse et al., 2000). Vibriosis is characterized by diarrhea, primary septicemia, wound infections, or other extra-intestinal infections (Daniels et al., 2000). Numerous studies have been conducted to determine the relationship between Vibrio spp. abundance and environmental factors such as temperature, salinity, nutrients and dissolved oxygen. As a result, these water quality characteristics can be used in a predictive manner to determine when these pathogens may be present (Gayatri, 2011). Once consumers eat undercooked or 
contaminated fish, illness is inevitable (Rahimi et al., 2010). The typical clinical symptoms of $V$. parahaemolyticus poisoning are acute dysentery and abdominal pain, accompanied by diarrhea, nausea, vomiting, fever, chills, and waterlike stools (Shimohata and Takahashi, 2010). The feces of patients are mixed with mucus or blood, and their blood pressure decreases dreamily, leading to shock (Broberg et al., 2011). V. parahaemolyticus is very sensitive to heat (killed at $47^{\circ}-60^{\circ}$ C) and to ionizing radiation, as well as to halogens (Adams and Moss, 2008). Thermal processing is one of the most common methods for achieving safe convenience fish products with an extended shelf life. The aim of this study was to investigate the incidence of Vibrio spp. in marine fish, fresh water fish and farm water fish as well as studying the effect of heat treatments (frying and roasting) on it.

\section{Material and methods:}

Part I: Isolation of Vibrio species

\subsection{Collection of the samples}

A grand total of 150 random samples of marine (Mullet, Sea Bream, Altobar), fresh water (Tilapia nilotica) and farm water (Mullet and Tilapia) fish (50 of each) were collected from Sharkia governorate during summer of 2014. All samples were collected and transferred with a minimum of delay to the laboratory in ice box. All samples were subjected to the bacteriological examination.

\subsection{Preparation of samples:}

The scales and fins of the fish were removed, the skin was sterilized by alcohol and flamed by sterile spatula. The muscles above the lateral line were removed, five grams were taken under aseptic conditions to sterile homogenizer containing $45 \mathrm{ml}$ of sterile alkaline peptone water $(3 \% \mathrm{Nacl}$ and $\mathrm{pH} 8$ ).

\subsection{Screening of Vibrio spp.}

It was done according to FDA (2004)

Isolation: Loopfuls from each previous cultured tubes were separately streaked onto Thiosulfate citrate bile and sucrose agar (TCBS), then the medium was incubated at $37^{0} \mathrm{C}$ for $24 \mathrm{hrs}$. Typical colonies of $V$. mimicus, $V$. parahaemolyticus and $V$. vulnificus were appeared as smooth and green (sucrose negative), while colonies of $V$. cholerae, $V$. furnissii, V. alginolyticus and V. fluvialis were appeared as smooth and yellow (sucrose positive).

Presumptive identification: This was done according to the protocol recommended by ISO/ TS 21872-1 (2007) and ISO/ TS 21872-2 (2007).

Part II: Effect of Heat Treatment on $V$. paraheamolyticus count

\subsection{Bacterial strain}

$V$. parahaemolyticus was obtained from the Food Microbiology Laboratory. $V$. parahaemolyticus was maintained on trypticase soy agar slants (containing $3 \% \mathrm{Nacl})$ at $4^{0} \mathrm{C}$. A loopful of $V$. parahaemolyticus was transferred aseptically into $10 \mathrm{ml}$ sterile Alkaline Peptone Water plus 3\% $\mathrm{Na} \mathrm{cl}$ and followed by cultivating separately at $37^{\circ} \mathrm{C}$ for $24 \mathrm{hrs}$ in shaker incubator. After incubation $V$. parahaemolyticus was counted by using spread plate method (FDA, 2001) and then adjusted to $\sim 10{ }^{6} \mathrm{CFU} / \mathrm{ml}$ (Shirazinejad and Ismail, 2010) with tube dilution method.

\subsection{Fish fillet Samples}

A total of 2 groups of fish fillet (5 pieces for each). All samples were washed in sterile distilled water and disinfected with alcohol.

\subsection{Artificial Contamination of fish fillet samples with $V$. parahaemolyticus}

Samples were dipped in 100ml Tryptic Soy Broth containing a $24 \mathrm{hrs}$-old culture (with $\sim 10^{6} \mathrm{CFU} / \mathrm{ml}$ ) (Shirazinejad and Ismail, 2010) and left for $30 \mathrm{~min}$. at room temperature to allow attachment. The 
contaminated samples were stored in sterile glass beakers covered with glass lids at ambient temperature $\left(30 \pm 2^{\circ} \mathrm{C}\right) . \quad V$. parahaemolyticus in the samples was enumerated to get the initial load before treatments was performed according to Terzi and Gucukoglu (2010).

\subsection{Heat treatment :( roasting and frying) (Pearson and Tauber,1984)}

Five pieces of contaminated fish fillet with known $V$. parahaemolyticus load (100g of each) were wrapped separately with aluminum foil then put into oven at $150{ }^{\circ} \mathrm{C}$ for 10 minutes. Another five pieces were used to study the effect of frying with cotton seed oil $\left(190{ }^{0} \mathrm{C}\right)$ for 10 minutes. After roasting and frying, the microbial counts of $V$. parahaemolyticus were done. The initial counts of control raw samples were also recorded and calculated.

\subsection{Bacteriological Analysis}

From each sample $10 \mathrm{~g}$ were taken under aseptic conditions to sterile homogenizer containing $90 \mathrm{ml}$ peptone water $(3 \% \mathrm{Nacl})$ then the contents were homogenized at $3000 \mathrm{rpm}$ for 2.5 minutes The mixture was allowed to stand for 15 minutes at room temperature under aseptic conditions. The content of the flask were thoroughly mixed by shaking and $1 \mathrm{ml}$ was transferred into separated tubes each containing $9 \mathrm{ml}$ peptone water $(3 \% \mathrm{Nacl})$, from which tenfold serial dilutions up to $10^{-6}$ were prepared. From the prepared sample $0.1 \mathrm{ml}$ of each prepared serial dilutions were streaked over the surface of thiosulphate citrate bile sucrose agar plates (TCBS) and incubated at $37^{\circ} \mathrm{C}$ for $24 \mathrm{hrs}$ (Thatcher and Clark, 1978). Rounded colonies $2-3 \mathrm{~mm}$ in diameter, with green and/or blue centers were recorded as $V$. parahaemolyticus.

\section{RESULTS}

Incidence of Vibrio spp. isolated from the examined samples of fish recorded in Table (1) were $26 \%, 48 \%$ and $43 \%$ for freshwater
, marine and farm water fish respectively. Incidence of Vibrio sp. in examined Freshwater Fish samples recorded in Table (2) revealed that incidence in the samples was $1(2 \%)$ for $V$. alginolyticus and were $2(4 \%)$ for each of $V$. damsela, $V$. fluvialis ,$V$. furnissi and $V$. mimicus and for $V$. vulnificus was 4(8\%), while $V$. cholerae and $V$. parahaemolyticus failed to be detected biochemically. Incidence of Vibrio spp. in examined fish samples collected from marine water was illustrated in Table (3) which revealed that incidence in the samples were 2(4\%) for each of $V$. alginolyticus and $V$. damsela, while, for $V$. vulnificus and $V$. fluvialis were $4(8 \%)$ for each. For $V$. parahaemolyticus was $5(10 \%)$ and for $V$. mimicus was 7 (14\%), while, $V$. cholerae failed to be detected biochemically. The incidence of Vibrio spp. in examined Farm water Fish samples recorded in Table (4) revealed that incidence in the samples was $1(2 \%)$ for $V$. parahaemolyticus and was $2(4 \%)$ for $V$. alginolyticus and was $3(6 \%)$ for each of $V$. damsela, $V$. fluvialis and $V$. vulnificus and was $5(10 \%)$ for $V$. mimicus, while, $V$. cholerae and failed to be detected biochemically. The influence of cooking using oven and frying on the count of $V$. parahaemolyticus $\left(1 \times 10^{6}\right)$ inoculated into fish fillet samples are shown in Table (5). Before cooking, the obtained results revealed that the count of $V$. parahaemolyticus was $105 \mathrm{cfu} / \mathrm{g}$. After roasting, the maximum count was $3 \times 10^{3}$ $\mathrm{cfu} / \mathrm{g}$ and the minimum count was $1 \times 10^{3}$ $\mathrm{cfu} / \mathrm{g}$ with mean value of $1.8 \times 10^{3} \pm 3.3 \times 10^{2}$. Therefore, the reduction percent in total count of $V$. parahaemolyticus was $98.2 \%$. While after frying $V$. parahaemolyticus was completely destroyed and the reduction $\%$ was $100 \%$.

Table (1): Incidence of Vibrio species isolated from the examined samples of fish $(n=50$ of each type) 


\begin{tabular}{lcc}
\hline \multicolumn{1}{c}{ Fish type } & Positive samples & $\%$ \\
\hline Fresh water fish & 13 & 26 \\
Marine fish & 24 & 48 \\
Farm water fish & 17 & 34 \\
\hline
\end{tabular}

Table (2): Incidence of Vibrio species isolated from Fresh Water Fish

\begin{tabular}{lcc}
\hline \multicolumn{1}{c}{ Isolate } & Number & $\%$ \\
\hline V. vulnificus & 4 & 8 \\
V. mimicus & 2 & 4 \\
$V$. fluvialis & 2 & 4 \\
$V$. damsel & 2 & 4 \\
$V$. furnissi & 2 & 4 \\
V. alginolyticus & 1 & 2 \\
\hline
\end{tabular}

Table (3): Incidence of Vibrio species isolated from Marine Water Fish

\begin{tabular}{lcc}
\hline \multicolumn{1}{c}{ Isolate } & Number & $\%$ \\
\hline V. parahaemolyticus & 5 & 10 \\
V. vulnificus & 4 & 8 \\
V.fluvialis & 4 & 8 \\
V. mimicus & 7 & 14 \\
V. alginolyticus & 2 & 4 \\
V. damsel & 2 & 4 \\
\hline
\end{tabular}

Table (4): Incidence of Vibrio species isolated from Farm Water Fish

\begin{tabular}{lcc}
\hline \multicolumn{1}{c}{ Isolate } & Number & $\%$ \\
\hline V. parahaemolyticus & 1 & 2 \\
V. vulnificus & 3 & 6 \\
V. fluvialis & 3 & 6 \\
V. mimicus & 5 & 10 \\
V. alginolyticus & 2 & 4 \\
V. damsela & 3 & 6 \\
\hline
\end{tabular}

Table (5): Influence of Heat Treatment on the count of $V$. parahaemolyticus. $(\mathrm{n}=5)$

\begin{tabular}{lccccc}
\hline \multicolumn{1}{c}{$\begin{array}{c}\text { Count } \\
(\mathrm{cfu} / \mathrm{gm})\end{array}$} & Before treatment & \multicolumn{3}{c}{ After treatment } & Reduction \% \\
\cline { 3 - 5 } & & Min. & Max. & Mean \pm SE & \\
\hline $\begin{array}{l}\text { Roasting } \\
\text { (oven- }\end{array}$ & $10^{5}$ & $1 \times 10^{3}$ & $3 \times 10^{3}$ & $1.8 \times 10^{3} \pm 3.3 \times 10^{2}$ & 98.2 \\
$150^{\circ} \mathrm{C} / 10$ min) & & & & & \\
$\begin{array}{l}\text { Frying } \\
\text { (cottonseed oil-boiling } \\
190^{\circ} \mathrm{C} / 10 \text { min) }\end{array}$ & $10^{5}$ & ND & ND & ND & 100 \\
\hline
\end{tabular}

\section{DISCUSSION}

It is evident from the results recorded in table (1) the high level of Vibrio spp. in marine fish when compared with samples from fresh and farm water fish this may be due to high salinity. Nearly similar results were obtained by Yücel and Balci (2010) and UCLA (2004).

Sanjeev (2002) reported the incidence of $V$. parahaemolyticus in fresh, marine and brackish water fish varied from 35 to $55 \%$. Also Todar (2005) mentioned that Vibriosis was wide spread in marine and freshwater habitats. Incidence of Vibrio spp. in examined Freshwater Fish samples recorded in Table (2) revealed that the incidence of Vibrio spp. was 13 (26\%), V. parahaemolyticus was detected in samples from Portugal (35\%) by Andrew et al. (2003). These results lower than those reported by Noorlis et al. (2011) who found that Vibrio spp. could be detected at a prevalence of $98.67 \%$, whereas $V$. parahaemolyticus was detected at a prevalence of $24 \%$ from examined fresh water fish. The presence of Vibrio spp. in samples of freshwater fish suggests that foodborne illness could arise if these fish are consumed in the uncooked or 
undercooked state. They could also crosscontaminate ready-to-eat foods that are in the same environment. Incidence of Vibrio spp. in examined Fish samples collected from Marine water fish was illustrated in Table (3) which revealed that the incidence of Vibrio spp. were 24 (48\%). These results nearly similar results those reported by Abd Ellatif (2013), John et al. (2011) and Slavica et al. (2002). On the other hand, higher results were reported by Engy (2006) and Jaksic et al. (2002) who isolated $V$. alginolyticus, $V$. fluvialis and $V$. mimicus from $14 \%, 9 \%$ and $28 \%$ of the examined samples of marine fish, respectively.

Lower results were recorded by Raissy et al. (2013) who revealed that $29.3 \%$ of the examined fish were Vibrio positive. This high incidence probably reflects the nature of Vibrio spp. which is known as a halophilic waterborne bacterium that commonly inhabits environmental water sources worldwide. The incidence of Vibrio spp. in examined farm water fish samples recorded in Table (4) revealed that the incidence of Vibrio spp. was 17(34\%). These results nearly similar to those of AbdEl-Latif et al. (2008) who isolated Vibrio spp. with a percentage of $33.75 \%$ from farm water fish. Gaber and Samy (2014) also reported that $32 \%$ of farm water fish were positive for Vibrio spp. These results are higher than results reported by Anwar et al. (2010) who detect Vibrio spp. in 16.8\% of the total examined fish. On the other hand, higher results were recorded by Ahmed and Naim (2005) who found that $58 \%$ of the total isolates were Vibrio spp. This may indicate bad management practices (inadequate nutrition, overcrowding and overfeeding) in fish farms which can cause stress to the fish being cultured and thus make them more susceptible to microbial infection. Aquaculture in Egypt remains a growing, vibrant and important production sector for high-protein animal food that is easily digestible and of high biological value. However, a major setback in aquaculture is the outbreak of diseases, especially those caused by Vibrio spp. which considered significant economic and public health problems.

The influence of cooking using oven and frying on the count of $V$. parahaemolyticus $\left(1 \times 10^{6}\right)$ inoculated into fish fillet samples were shown in Table (5). Before cooking, the obtained results revealed that the count of $V$. parahaemolyticus was $10^{5} \mathrm{cfu} / \mathrm{g}$. After roasting, the maximum count was $3 \times 10^{3} \mathrm{cfu} / \mathrm{g}$ and the minimum count was $1 \times 10^{3} \mathrm{cfu} / \mathrm{g}$ with mean value of $1.8 \times 10^{3}$ $\pm 3.3 \times 10^{2}$. Therefore, the reduction percent in total count of $V$. parahaemolyticus was $98.2 \%$. While after frying $V$. parahaemolyticus was completely destroyed and the reduction \% was $100 \%$. Accordingly, the best and fast method for heat treatment of fish was by frying for $10 \mathrm{~min}$. at $190^{\circ} \mathrm{C}$. Such results agree with those reported by Abd Ellatif (2013) who recorded that $V$. parahaemolyticus count reduced by $99.2 \%$ after cooking in oven $120^{\circ} \mathrm{C} / 35 \mathrm{~min}$. and $100 \%$ after frying. Also, ICMSF (1996) which stated that $V$. parahaemolyticus can be killed when boiling at least $64^{\circ} \mathrm{C}$ for more than 90 seconds.

\section{REFERENCES}

Abd-El-Latif, M.M., Moustafa, A.H. and Adawy, R.S.M. 2008. Some studies on Vibriosis in farmed Mugil cephalus in Dakahlia governorate. Assiut Veterinary Medical Journal, 19(1). 54(118):177-185.

Abd Ellatif, Z.A. 2013. Vibrio parahaemolyticus in marine fish. Department of food control ,Faculty of Veterinary Medicine, Benha University, pp. 41-43

Adams, M.R. and Moss, M.O. 2008. Bacterial agents of food borne illness In: Food Microbiology (3rd Ed.) RSC, Surrey UK, pp. 182-269.

Ahmed, H. Al-Harbi and Naim Uddin, 2005. Bacterial diversity of tilapia (Oreochromis niloticus) cultured in 
brackish water in Saudi Arabia Aquaculture. 250(3-4): 566-572

Altekruse, S.F.; Bishop, R.D. and Baldy, L.M. 2000. Vibrio gastroenteritis in the US Gulf of Mexico region, the role of raw oysters. Epidemiol. Infect 124:489-95

Andrews, L.; Jahncke, $\mathrm{M}$.and Mallikarjunan, K. 2003. Low dose gamma irradiation to reduce pathogenic Vibrio in live oysters (Crassostreavirginica). J. Aquat. Food Prod.Technol. 12:71-82.

Anwar E. Al-Sunaiher; Abdelnasser S.S. Ibrahim and Ali A. Al-Salamah 2010. Association of Vibrio Species with Disease Incidence in Some Cultured Fishes in the Kingdom of Saudi Arabia. World Applied Sciences Journal 8(5):653-660.

Broberg, C. A.; Calder, T. J. and Orth, K. 2011.Vibrio parahaemolyticus cell biology and pathogenicity determinants. Microbes Infect. 13:992-1001.

Daniels, N. A.; Mackinnon, L.; Bishop, R.; Altekruse, S.; Ray, B.; Hammond, R. M.; Thompson, Sh.; Wilson, S.; Bean. N, H.; Griffin, P. M. and Slutsker, L. 2000. Vibrio parahaemolyticus Infections in the United States, 19731998. J. Infect. Dis., 181(5):16611666.

Engy, F. A. El-Bahy 2006. Vibrio parahaemolyticus and some halophilic bacteria associated with fish and shellfish. Department of food control, Faculty of Veterinary Medicine, Alexandria University, pp. 35.

Food and Drug Administration (FDA) 2001. Methods for Specific Pathogens: Escherichia coli ,Salmonella and Vibrio, 8th Ed. FDA Center for Food Safety and Applied Nutrition ,Bacteriological Analytical Manual. Available at www.cfsan.fda.gov/ ebam/bamtoc.html
Food and Drug Administration (FDA) 2004. Bacteriological Analytical Manual, Vibrio Chapter-9 (BAM).

Gaber, S. Abdellrazeq and Samy A. Khaliel 2014. Molecular Characterization and Antimicrobial Susceptibility of Vibrios Isolated from Healthy and Diseased Aquacultured Freshwater Fishes, Department of Microbiology, Faculty of Veterinary Medicine, Alexandria University, Edfina, Rosetta-line, Egypt. Global Veterinaria 13(3):397-407

Gayathri, V. 2011. The prevalence and public health significance of human pathogenic Vibrio species in Hawai'i's diverse tropical coastal water environments.

Hibbeln, J. R.; Davis, J. M. ; Steer, C.; Emmett, P.; Rogers, I.; Williams, C. and Golding, J. 2007. Maternal seafood consumption in pregnancy and neurodevelopmental outcomes in childhood (ALSPAC study): an observational cohort study. Lancet 369:578-585.

International Commission on Microbiological Specifications for Foods (ICMSF) 1996. Vibrio cholerae. In: Microorganisms in Foods 5. Characteristics of Microbial Pathogens. London: Blackie Academic \& Professional; pp. 414425.

International Organization for standardization/technical specification (ISO/TS21872-1) 2007. Specifies a horizontal method for the detection of the two main pathogenic vibrio species causing intestinal illness in humans: $V$. parahaemolyticus and $V$. cholerae.

International Organization for standardization/technical specification (ISO/TS21872-2) 2007. Specifies a horizontal method for the detection of the enteropathogenic Vibrio species, causing illness in or via the intestinal tract, other than $\mathrm{V}$. 
parahaemolyticus and $\mathrm{V}$. cholerae. Include V. fluvialis ,V. mimicus and $\mathrm{V}$. vulnificus.

Jaksic, S.; Uhitil, S.; Patrak, T.; Bazulic, D. and Karolyi, L.G. 2002. Occurrence of Vibrio spp. In sea fish, shrimps and bivalve mollusks from the Adriatic Sia. Food Control; 13:491-493.

John, M.O., Odu, N.N., Nwanze, J.C., Adebayo-Tayo, B.C., Okonko, I.O. and Ezediokpu, N. 2011. Occurrence of Potentially Pathogenic Vibrio Species in Sea Foods Obtained from Oron Creek Advances in Biological Research 5(6):356-365.

Noorlis, A.; Ghazali, F. M.; Cheah, Y. K.; Tuan Zainazor, T. C.; Ponniah, J.; Tunung, R.; Tang, J. Y. H.; Nishibuchi, M.; Nakaguchi, Y. and Son, R. 2011. Prevalence and quantification of Vibrio species and Vibrio parahaemolyticus in freshwater fish at hypermarket level. International Food Research Journal 18: 689-695

Pearson, P.A and Tauber, W.F. 1984. Processed meat $2^{\text {nd }}$ Ed. AVI publication, INC., West Port. CT.

Rahimi, E.; Ameri, M.; Doosti, A. and Gholampour, A. R. 2010. Occurrence of toxigenic Vibrio parahaemolyticus strains in shrimp in Iran. Foodborne Pathogen and Diseases. (7):11071111.

Raissy, M.; Rahimi, E.; Azargun, R. ; Moumeni, M.; Rashedi, M. and Sohrabi, H. R. 2013. Molecular Detection of Vibrio spp. in Fish and Shrimp from the Persian Gulf .Journal of Food Biosciences and Technology, Islamic Azad University, Science and Research Branch, 5(2):49-52.

Sanjeev, S. 2002. Pathogenic halophilic Vibrios in seafoods. In: Quality Assurance in Seafood Processing, 252pp. T.S. Gopala Krishna Iyer, M.K. Kandoran, Mary Thomas and P.T Mathew (Eds). Central Institute of Fisheries Technology and Society of Fisheries Technologists (India), Cochin.

Shimohata, T. and Takahashi, A. 2010. Diarrhea induced by infection of Vibrio parahaemolyticus. J. Med. Invest., 57:179-182.

Shirazinejad, A. and Ismail, N. 2010. Effect of lactate treatments on survival of foodborne pathogens in frozen shrimp. American J. Agricultural and Biological Sciences, 5:242-246.

Slavica Jak, Si. C. ; Suncica, U.; Petrak, T.; Bazulic, D. and Lada, G. K. 2002. Occurrence of Vibrio spp. in sea fish, shrimps and bivalve mollusks harvested from Adriatic sea. www.elsevier.com/locate/foodcont Food Control 13:491-493.

Terzi ,G. and Gucukoglu, A. 2010. Effects of lactic acid and chitosan on the survival of $V$. parahaemolyticus in mussel samples. J. Animal and Veterinary Advances, 9:990-994.

Thatcher, F.S. and Clark, 1978. Microorganisms in foods. Their Significance and methods of enumeration. $2^{\text {nd }}$ Ed. Academic Press, New York.

Todar, K. 2005. Vibrio cholerae and Asiatic cholera. http://textbook of bacteriology.net/cholera.html.

University of California, Los Angres Marine science center (UCLA) 2004. Density and salinity, A Curriculum in Marine Sciences,3-6

Velusamy, V.; Arshak, K.; Korastynska, O.; Oliwa, K. and Adley, C. 2010. An overview of food borne pathogen detection in the perspective of Biosensors. Biotechnology Advances, 28: 232-254.

Yücel, N. and Balci, Ş. 2010. Prevalence of Listeria, Aeromonads, and Vibrio Species in Fish used for Human Consumption in Turkey. Journal of Food Protection, 2: $212-404$ 